\title{
Abnormal Regulation of Ribosomal Protein S6 Kinase by Insulin in Skeletal Muscle of Insulin-resistant Humans
}

\author{
James Sommercorn, Rose Fields, Itamar Raz, and Ryo Maeda \\ Clinical Diabetes and Nutrition Section, National Institute of Diabetes and Digestive and Kidney Diseases, \\ National Institutes of Health, Phoenix, Arizona 85016
}

\begin{abstract}
Insulin resistance in Pima Indians appears to result from a post-receptor impairment of insulin signal transduction that affects only some responses to insulin. To identify the primary lesion responsible for insulin resistance, we investigated the influence of insulin on ribosomal protein S6 kinase activities in skeletal muscle of insulin-sensitive and insulin-resistant nondiabetic Pima Indians during a 2-h hyperinsulinemic, euglycemic clamp. In sensitive subjects, S6 kinase activity was transiently activated fivefold over basal activity by $45 \mathrm{~min}$ of insulin infusion. Although basal activities in the two groups were similar, the response to insulin was delayed and restricted to about threefold over basal in subjects resistant to insulin. Two major S6 kinase activities in extracts of human muscle were resolved by chromatography on Mono $Q$. Peak 1 , which accounted for basal activity owes to an enzyme antigenically related to the 90-kD S6 kinase II, a member of the rsk gene family. The major insulin-stimulated S6 kinase eluted as peak 2 and is antigenically related to a 70-kD S6 kinase. Our results show that insulin resistance impairs signaling to the 70-kD S6 kinase. $(J$. Clin. Invest. 1993. 91:509-513.) Key words: non-insulin-dependent diabetes mellitus • insulin resistance $\bullet$ insulin signal transduction • protein phosphorylation • protein kinase
\end{abstract}

\section{Introduction}

Impaired response of skeletal muscle to insulin may be an early expression of the genetic abnormality that causes non-insulindependent diabetes mellitus in Pima Indians (1) and in other populations (2). Because insulin receptor cDNAs from insulin-resistant Pima Indians predict a normal protein structure $(3,4)$ and studies of insulin binding and stimulation of the receptor protein tyrosine kinase activity in vitro have not revealed abnormalities that could account for insulin resistance (5), the condition in Pima Indians likely results from a post-receptor defect in the mechanism of insulin signal transduction. This defect limits the ability of insulin to suppress protein tyrosine phosphatase activity (6) and to activate glycogen synthase (7), glycogen synthase phosphatase (8), and type 1 protein phosphatase (9) in skeletal muscle. However, regulation of casein kinase II by insulin does not appear to be impaired in

Part of this work has appeared in abstract form (1990. FASEB [Fed. Am. Soc. Exp. Biol.] J. 4:2079a.)

Address correspondence and reprint requests to James Sommercorn, Ph.D., Clinical Diabetes and Nutrition Section, National Institutes of Health, 4212 N. 16th St., Phoenix, AZ 85016. 1992.

Received for publication 24 April 1992 and in revised form 3 August

The Journal of Clinical Investigation, Inc.

Volume 91, February 1993, 509-513 insulin-resistant Pima Indians (10), which suggests that it contributes to insulin action either upstream from the defect or in a separate pathway of insulin action.

To map the primary defect in the insulin signal transduction pathway that limits insulin action in resistant subjects, we examined the influence of insulin on activities of serine/ threonine-specific protein kinases known to contribute to insulin signaling (11), in skeletal muscle of insulin-sensitive and -resistant subjects in vivo. Here, we report our findings on activities of ribosomal protein S6 kinases.

\section{Methods}

Hyperinsulinemic euglycemic clamp and muscle biopsy. After giving written informed consent, volunteers were admitted to the clinical research ward and given physical examinations. After an overnight fast, routine blood chemical and hematological examinations were performed. All subjects had normal physical examinations, electrocardiograms, and blood tests, and none were taking medications. After a minimum of $2 \mathrm{~d}$ on a standard diet, each underwent a 75 -g oral glucose tolerance test and underwater weighing to estimate body composition. The characteristics of the subjects and results of oral glucose tolerance tests are presented in Table I. Hyperinsulinemic, euglycemic clamps at a maximally stimulating plasma insulin concentration and multiple biopsies of the vastus lateralis muscle were performed as described (10). After the first biopsy, a primed continuous insulin infusion (600 $\left.\mathrm{mU}\left[\mathrm{m}^{2}\right]^{-1}[\mathrm{~min}]^{-1}\right)$ was given for $2 \mathrm{~h}$. Based on the rate of glucose disposal during the last $40 \mathrm{~min}$ of the clamp, and on criteria established by the World Health Organization (12), subjects were classified as nondiabetic and either insulin sensitive (glucose disposal rate $\geq 8 \mathrm{mg}$ [ $\mathrm{min}^{-1}[\mathrm{~kg} \text { fat-free mass }]^{-1}$ ) or insulin resistant (glucose disposal rate $<6 \mathrm{mg}[\mathrm{min}]^{-1}\left[\mathrm{~kg}_{\text {fat-free mass }}{ }^{-1}\right.$ ). Glucose disposal rates and concentrations of glucose and insulin in plasma before and at steady state during the clamp are summarized in Table II.

Extracts of muscle. Muscle obtained by biopsy was frozen in liquid nitrogen within $15 \mathrm{~s}$ and stored at $-70^{\circ} \mathrm{C}$ before it was processed as described (10). Dried muscle powder was mixed with buffer comprising $80 \mathrm{mM}$ beta-glycerophosphate, $20 \mathrm{mM} \mathrm{EGTA}, 15 \mathrm{mM} \mathrm{MgCl}_{2}, \mathrm{pH}$ 7.3 , at a ratio of $0.25 \mathrm{ml}$ of buffer $/ \mathrm{mg}$ and disrupted at $4^{\circ} \mathrm{C}$ using a polytron. The homogenates were centrifuged at $100,000 \mathrm{~g}$ for $30 \mathrm{~min}$ at $4^{\circ} \mathrm{C}$, and the supernatant fractions were retained and assayed for $\mathrm{S} 6$ kinase activity.

FPLC mono $Q$ chromatography. $20 \mathrm{mg}$ of dry muscle powder was homogenized with a polytron in $2.3 \mathrm{ml}$ of buffer comprising $50 \mathrm{mM}$ beta-glycerophosphate, pH 7.3, $1.5 \mathrm{mM}$ EGTA, $1 \mathrm{mM}$ DTT, and 0.1 $\mathrm{mM} \mathrm{Na}_{3} \mathrm{VO}_{4}$ (buffer A). The homogenate was centrifuged at $100,000 \mathrm{~g}$ for $30 \mathrm{~min}$ at $4^{\circ} \mathrm{C}$, and the resultant supernate was injected onto a $1-\mathrm{ml}$ Mono $Q$ column in a cold room at a flow rate of $1 \mathrm{ml} / \mathrm{min}$. After washing the column with $5 \mathrm{ml}$ of buffer A, a linear gradient of $0-0.5 \mathrm{M}$ $\mathrm{NaCl}$ in buffer $A$ was started at a flow rate of $0.5 \mathrm{ml} / \mathrm{min}$. The first seven fractions were of $1 \mathrm{ml}$ vol and subsequent fractions were $0.2 \mathrm{ml}$. In a preliminary experiment, a $0-1-\mathrm{M} \mathrm{NaCl}$ gradient was run. No additional S6 kinase activity was eluted with a salt concentration $>0.5 \mathrm{M}$ (data not shown).

S6 kinase assay. $40 \mathrm{~S}$ ribosomal subunits were isolated from livers of rats that had been fasted overnight (13). Aliquots of muscle extracts 
Table I. Characteristics of Insulin-sensitive and-resistant Subjects

\begin{tabular}{lcc}
\hline & Sensitive & Resistant \\
\hline$n$ & 7 & 4 \\
Age, yr & $27 \pm 2$ & $40 \pm 3^{\ddagger}$ \\
Height, cm & $167 \pm 2$ & $170 \pm 4$ \\
Weight, $\mathrm{kg}$ & $80.5 \pm 9.3$ & $129.8 \pm 10.7^{\ddagger}$ \\
BMI $^{8}, \mathrm{~kg} / \mathrm{m}^{2}$ & $28.7 \pm 3.2$ & $45.0 \pm 3.3^{*}$ \\
Body fat, \% & $23 \pm 4$ & $38 \pm 2^{*}$ \\
OGTT & & \\
\multicolumn{1}{c}{ FPG, mg/dl } & $93 \pm 4$ & $111 \pm 3^{*}$ \\
2hPG, mg/dl & $113 \pm 5$ & $179 \pm 17^{\ddagger}$ \\
\hline
\end{tabular}

Insulin sensitivity is based on the glucose disposal rate during the last $40 \mathrm{~min}$ of a hyperinsulinemic, euglycemic clamp (see Table II). ${ }^{*} P$ $<0.05$ vs sensitive, $t$ test. ${ }^{\ddagger} P<0.01$ vs sensitive, $t$ test. ${ }^{\S} \mathrm{BMI}$, body mass index calculated as weight $(\mathrm{kg})$ divided by height $(\mathrm{m})$ squared; OGTT, oral glucose tolerance test; FPG, fasting plasma glucose; $2 \mathrm{hPG}$, plasma glucose $2 \mathrm{~h}$ after ingestion of $75 \mathrm{~g}$ of glucose. Data are means \pm SEM.

or Mono $\mathrm{Q}$ fractions were assayed for $\mathrm{S} 6$ kinase activity at $30^{\circ} \mathrm{C}$ in the presence of $20 \mathrm{mM}$ Hepes, $\mathrm{pH} 7.5,10 \mathrm{mM} \mathrm{MgCl}_{2}, 5 \mathrm{mM}$ DTT, $60 \mu \mathrm{M}$ $\left[\gamma-{ }^{32} \mathrm{P}\right]$-ATP $(4,000-4,500 \mathrm{cpm} / \mathrm{pmol}), 120 \mu \mathrm{M} \mathrm{Na} \mathrm{VO}_{4}, 0.5 \mu \mathrm{M}$ protein kinase inhibitor 5-24 peptide (product code 8883; Peninsula Laboratories, Inc., Belmont, CA), $0.02 \%$ Triton X-100, and either 3.6 $\mathrm{A}_{260} \mathrm{U}$ (muscle extracts) or $1.8 \mathrm{~A}_{260} \mathrm{U}$ (column fractions) of $40 \mathrm{~S} / \mathrm{ml}$ in a total volume of $50 \mu \mathrm{l}$. Reactions were stopped after $20 \mathrm{~min}$ by adding $35 \mu$ of $3 \times$ Laemmli sample buffer (14) and heating in boiling water for $5 \mathrm{~min}$. Proteins in the reaction mixture were resolved by SDSPAGE on $12.5 \%$ polyacrylamide gels, which were then stained with Coomassie brilliant blue-R, destained, and dried. After autoradiography, the labeled S6 protein was cut from the gels and incorporated radioactivity was estimated by liquid scintillation spectrometry. Protein was assayed as described by Bradford (15).

Immunoblots. Proteins in individual fractions obtained from Mono Q chromatography were precipitated with $10 \%$ TCA in the presence of $200 \mu \mathrm{g}$ of carrier ovalbumin and collected by sedimentation at $15,000 \mathrm{~g}$ for $5 \mathrm{~min}$. The pellets were solubilized by mixing with $75 \mu \mathrm{l}$ of $3 \times$ Laemmli sample buffer (14) for $1 \mathrm{~h}$. Basic $\mathrm{pH}$ of the samples was maintained by adding $0.2 \mathrm{~N} \mathrm{NaOH}$. Pooled fractions of $\mathrm{S} 6$ kinase were concentrated with centrifugal concentrators and proteins were denatured in Laemmli sample buffer. The samples were boiled for $5 \mathrm{~min}$ and proteins were resolved by SDS-PAGE on a $7.5 \%$ polyacrylamide

Table II. Results of Hyperinsulinemic, Euglycemic Clamps in Insulin-sensitive and -resistant Subjects

\begin{tabular}{lcc}
\hline & Sensitive & Resistant \\
\hline$n$ & 7 & 4 \\
$\begin{array}{l}\text { Glucose }(\mathrm{mg} / \mathrm{dl}) \\
\quad \text { Before }\end{array}$ & $102 \pm 4$ & $114 \pm 5$ \\
$\quad$ Steady state & $94 \pm 1$ & $96 \pm 1$ \\
$\begin{array}{l}\text { Insulin }(\mu \mathrm{U} / \mathrm{ml} \text { plasma) } \\
\quad \text { Before }\end{array}$ & $9 \pm 2$ & $41 \pm 7^{*}$ \\
$\quad$ Steady state & $227 \pm 144$ & $2646 \pm 174$ \\
$\begin{array}{l}\text { Glucose disposal rate } \\
\quad\left(\mathrm{mg}[\mathrm{min}]^{-1}[\mathrm{~kg} \text { of FFM] }]^{-1}\right)^{\ddagger}\end{array}$ & $10 \pm 1$ & $4 \pm 1^{*}$ \\
\hline
\end{tabular}

${ }^{*} P<0.001$ vs sensitive, $t$ test. ${ }^{\ddagger}$ FFM, fat-free mass as determined by underwater weighing. Data are means \pm SEM. gel and electrotransferred to nitrocellulose, which was then blocked as described (16). Blots were developed with either a 1/100 dilution of antiserum to rat liver 70K S6 kinase (antiserum 1321 obtained from Dr. J. Avruch, Massachusetts General Hospital, Charlestown, MA) or with a 1/250 dilution of anti-rsk antibody (antiserum 125, raised against bacterially expressed S6 kinase II, and obtained from Dr. R. Erikson, Harvard University, Boston, MA) followed by $\mathrm{I}^{125}$-protein A and autoradiography (16).

\section{Results}

Infusion of insulin resulted in a rapid, transient increase in S6 kinase activity in extracts of muscle obtained from insulin-sensitive subjects (Fig. 1). The majority of the activation occurred between 15 and 30 min of insulin infusion and reached a maximum of approximately fivefold over basal activity at $45 \mathrm{~min}$ before declining. Basal activities in insulin-sensitive and -resistant subjects were similar, but the response to insulin of S6 kinase activity in muscle of insulin-resistant subjects was restricted and delayed (Fig. 1). Insulin increased activity in resistant subjects only about threefold and the maximum was not reached until $60 \mathrm{~min}$. S6 kinase activity in the two groups appeared to decline toward basal levels at similar rates.

The lack of a large increase in S6 kinase activity between 15 and $30 \mathrm{~min}$ of insulin infusion in muscle of insulin-resistant subjects was striking (Fig. 1). To determine if this difference reflected impaired activation of a particular S6 kinase enzyme, S6 kinase activities in skeletal muscle were resolved by Mono $Q$ chromatography (Fig. 2). In muscle of both insulin-sensitive and insulin-resistant subjects, insulin-stimulated S6 kinase activity can be accounted for by two major activities, labeled peaks 1 and 2. The small shoulder to peak 1 (labeled 1A) was observed in all separations. In both groups of subjects, S6 kinase(s) eluting as peaks 1 and $1 \mathrm{~A}$ account for basal activity; there is virtually no activity eluting as peak 2 . At a time of maximal insulin stimulation, S6 kinase activities are increased in both insulin-sensitive and -resistant subjects, but the increases in the resistant subject are less.

To assess the contributions of the two major $\mathbf{S 6}$ kinase activities to total insulin-stimulated activity during the timecourse

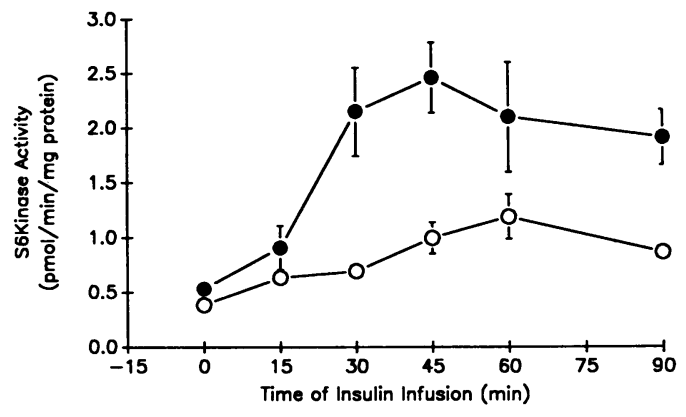

Figure 1. Activation of S6 kinase by insulin in human skeletal muscle. Biopsies of the vastus lateralis were obtained from insulin sensitive $(\bullet, n=7)$ or insulin-resistant $(0, n=4)$ subjects at the indicated times during a hyperinsulinemic, euglycemic clamp. Muscle was processed and S6 kinase activity was determined as described in Methods. Data are means \pm SEM. For some means, the error bar is masked by the symbol. Data were analyzed by repeated measures analysis of variance which showed a significant effect of insulin in both sensitive and resistant subjects $(P<0.01)$ and that the responses in the two groups were different from each other $(P=0.05)$. 


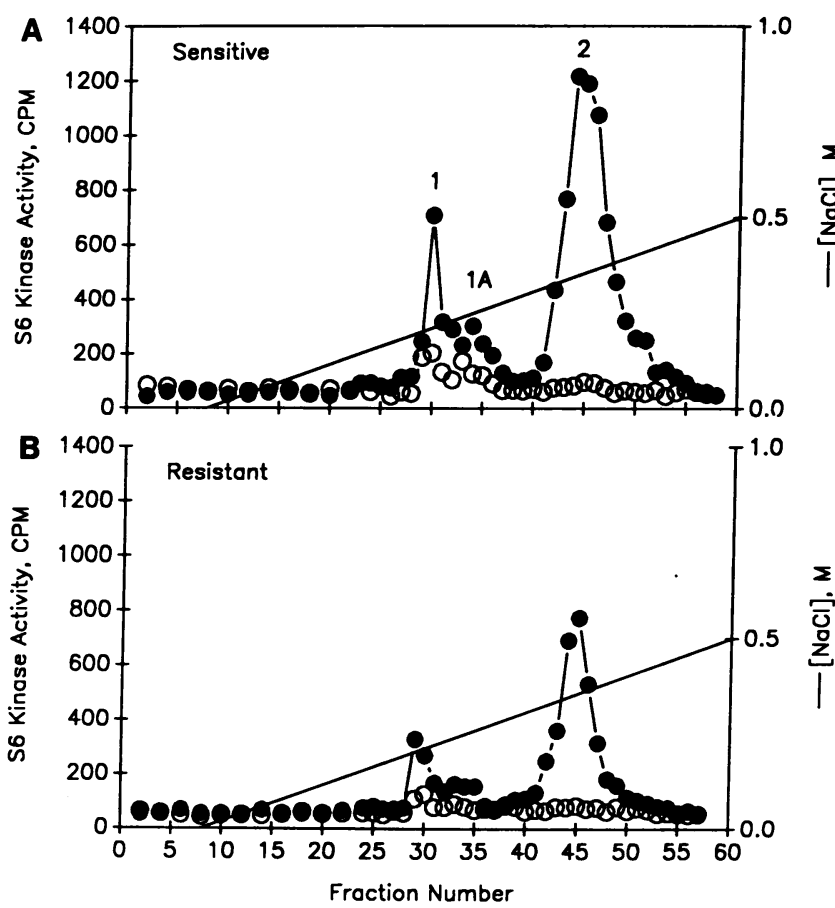

Figure 2. Separation of S6 kinase activities in human skeletal muscle on Mono Q. Extracts of muscle samples from an insulin-sensitive $(A)$ and an insulin-resistant subject $(B)$, taken before $(O)$ and at a time of maximal insulin stimulation $(\bullet)$, were subjected to Mono $\mathrm{Q}$ chromatography. S6 kinase activity in the fractions was assayed as described in Methods. Activities were normalized for the amount of muscle homogenized and for the specific radioactivity of ATP.

of activation, the enzymes in extracts of muscle obtained from an insulin-sensitive subject were resolved on Mono $Q$ and peak areas were integrated (Fig. 3). It is apparent that peak 2 accounts for nearly all of the insulin-stimulated S6 kinase activity at all three times after exposure to insulin. Nonetheless, peak 1 activity is activated nearly threefold at $45 \mathrm{~min}$.

Two major types of S6 kinase are distinguishable by molecular size. S6 kinase II, an enzyme with a relative molecular mass of $92 \mathrm{kD}$, was first purified from Xenopus eggs $(17,18)$. It is a member of the $r s k$ gene family, as is the related Xenopus 90-

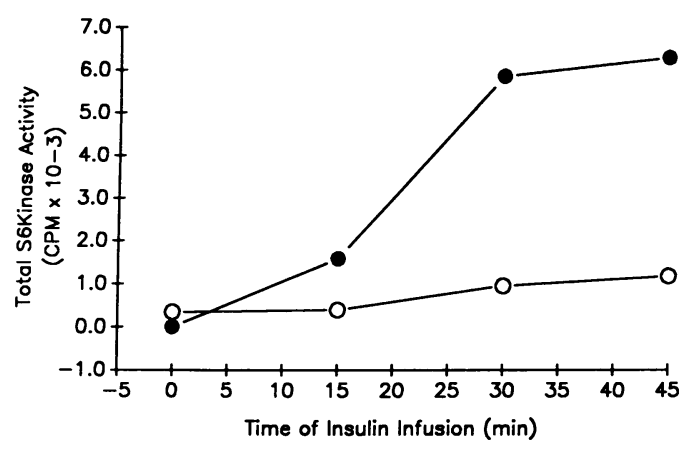

Figure 3. Timecourse of activation of $\mathbf{S 6}$ kinases by insulin in human skeletal muscle. S6 kinase activities in extracts of muscle samples from an insulin-sensitive subject were resolved by Mono $Q$ chromatography. Total S6 kinase activity in peaks $1(0)$ and $2(\bullet)$ (see Fig. 2 ) was calculated based on the volume of the fractions comprising the peaks. Activities were normalized for the amount of muscle homogenized and for the specific radioactivity of ATP.
kD S6 kinase I (18), and is expressed in a variety of tissues ( 19, $20)$. A second type of S6 kinase with a relative molecular mass of $70 \mathrm{kD}$, has been purified from several sources (21-25). To determine which of these $\mathrm{S} 6$ kinases contribute to the activities resolved on Mono Q (Fig. 2), fractions were subjected to immunoblotting. The blots were probed with antibodies to either $r s k$ protein or to a $70-\mathrm{kD}$ S6 kinase. Fig. $4 \mathrm{~A}$ shows that signal generated with anti-rsk antibody runs as a doublet with a relative molecular mass $\sim 86 \mathrm{kD}$ and that intensity of the signal coincides with S6 kinase activity eluting as peaks 1 and $1 \mathrm{~A}$. There was no signal generated with antibody to $70 \mathrm{kDa}$ S6 kinase in these fractions (data not shown) or in pooled fractions of peaks 1 and $1 \mathrm{~A}$ (Fig. $4 \mathrm{~B}$ ). The antibody to $70 \mathrm{kD} \mathrm{S6}$

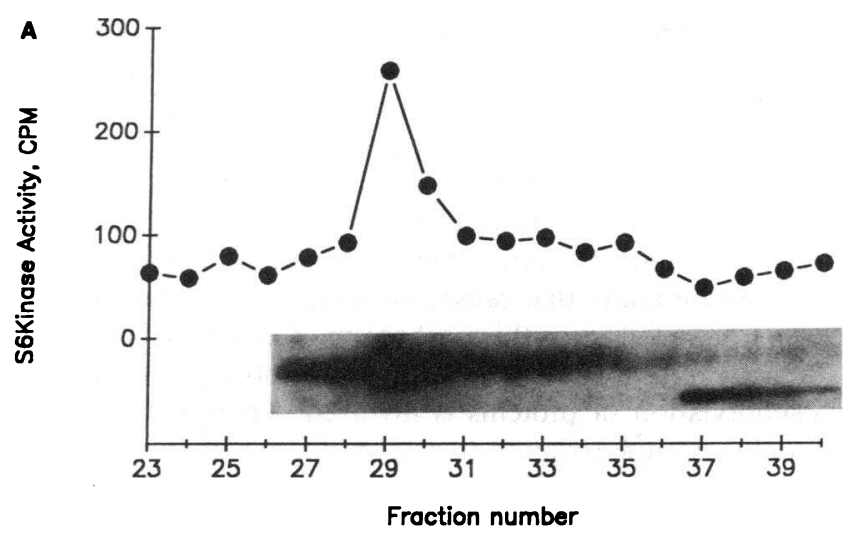

B

\section{Mono Q Peak}

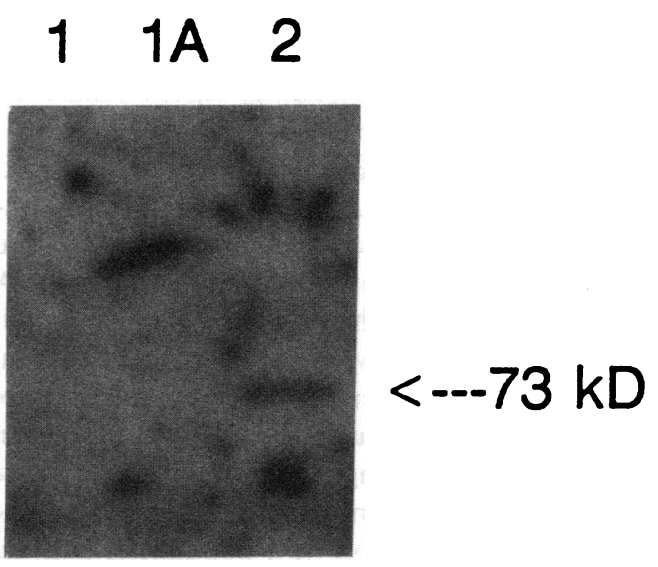

Figure 4. Immunologic identification of S6 Kinases in human muscle. (A) An extract of skeletal muscle obtained from an insulin-sensitive subject during insulin infusion was subjected to Mono $Q$ chromatography and the fractions were assayed for $\mathbf{S 6}$ kinase activity. Fractions 27-50 were subjected to immunoblotting with anti-rsk antibody. Fractions spanning peaks 1 and $1 \mathrm{~A}$ (see Fig. 2) are shown. The signal with intensity proportional to $\$ 6$ kinase activity in fractions 27-33 ran at a relative molecular mass of $\sim 86 \mathrm{kD}$. Anti-rsk antibody did not detect antigen in fractions corresponding to peak 2 (see Fig. 2), nor did antibody to 70-kD S6 kinase detect antigen in fractions corresponding to peaks 1 and $1 \mathrm{~A}$ (data not shown). (B) Mono $Q$ fractions corresponding to S6 kinase peaks 1, 1A, and 2 (see Fig. 2) were pooled, concentrated, and immunoblotted with antibody to a 70-kD S6 kinase. 
kinase did not detect antigen in individual fractions of peak 2, perhaps owing to low abundance of the protein or to low titer of the antibody. However, a band with a relative molecular mass equal to $73 \mathrm{kD}$ was detected in a concentrated pool of fractions comprising peak 2 (Fig. $4 \mathrm{~B}$ ). Anti-rsk antibody gave no signal in either individual peak 2 fractions or in the pooled peak 2 (data not shown). Based on these results, it appears that S6 kinase activity in peaks 1 and $1 \mathrm{~A}$ owes to a $r s k$-related enzyme(s) and that peak 2 activity owes to an enzyme related to the 70-kD S6 kinase.

\section{Discussion}

The Pima Indians have the highest known prevalence of noninsulin-dependent diabetes mellitus, a disease that may be inherited in this population as a single autosomal gene (1). Longitudinal studies have shown that the development of impaired glucose tolerance, which is characterized by a reduced capacity of skeletal muscle to respond to insulin, precedes and predicts development of non-insulin-dependent diabetes mellitus (26, 27). Thus, insulin resistance may be an early expression of the genetic abnormality that causes the disease. Insulin resistance results from a failure in the mechanism of insulin action. This mechanism is not entirely understood, however reversible phosphorylation of proteins is involved. Changes in serine/ threonine phosphorylation in response to insulin are effected by alterations in activities of serine/threonine-specific protein kinases (11) and phosphatases (8, 9, 28, 29).

Although some rare conditions of insulin resistance are caused by mutations of the insulin receptor (30), the receptor cDNAs from insulin-resistant Pima Indians predict a normal protein $(3,4)$. Furthermore, studies of insulin binding and regulation of the receptor protein tyrosine kinase activity in skeletal muscle have not revealed abnormalities that could account for insulin resistance (5) and activation of at least one post-receptor element of insulin-signaling, casein kinase II, does not appear to be impaired in insulin resistance (10). Nonetheless, insulin resistance affects the ability of the hormone to alter activities of 70-kD S6 kinase, protein tyrosine phosphatase (6), glycogen synthase (7), glycogen synthase phosphatase (8), and type 1 protein phosphatase (9), and to alter mRNA levels of certain genes, but not others (Thompson, B., and J. Sommercorn, unpublished observations). These differential effects of insulin resistance on elements of insulin action are consistent with evidence of at least two pathways of insulin signal transduction (31-34) and suggest that the primary cause of insulin resistance in Pima Indians may affect only one of the pathways. Studies of insulin action in a population with an inherent defect in one aspect of insulin signaling allows segregation of insulin responses into different pathways. This should facilitate application of advances in understanding of the mechanism of insulin action to our objective of determining the primary cause of insulin resistance in the Pima Indians.

Our findings that insulin resistance impairs both activation of 70-kD S6 kinase, which is thought to contribute primarily to regulation of protein synthesis, and signaling to the nucleus (see above) suggest that although insulin resistance has been defined in terms of glucose metabolism, it may be more accurate to think of it as an insulin signal deficiency that impairs many aspects of insulin function. The pathologic consequences of insulin resistance may result as much or more from im- paired regulation of gene expression or protein synthesis as from abnormal glucose homeostasis.

Among the larger effects of insulin on protein kinases is its stimulation of activity toward ribosomal protein S6, an effect that has been observed in a wide variety of cells and tissues. This large stimulation of S6 kinase activity was also detected in skeletal muscle of insulin-sensitive humans, but the response was impaired in those resistant to the hormone (Fig. 1). In this study, insulin-resistant subjects were significantly older and fatter than insulin-sensitive subjects (Table I). Therefore, we cannot rule out the possibility that abnormal regulation of S6 kinase activity is a function of age or obesity rather than insulin sensitivity. These alternative explanations are unlikely however, since others have shown that insulin action is not correlated with degree of obesity (35-37), and that glucose tolerance and insulin sensitivity are not correlated with age $(38,39)$ in the ranges reflective of the subjects in our study.

Kinases related to both the $r s k$ gene product and a 70-kD S6 kinase are expressed in human skeletal muscle. Our studies show that the major insulin-stimulated S6 kinase in human muscle is antigenically related to the $70-\mathrm{kD}$ enzyme, consistent with the fact that S6 kinase purified from cells or tissues exposed to insulin or growth-promoting stimuli has a relative molecular mass of $\sim 70 \mathrm{kD}(22-25)$. Our results also show that insulin resistance restricts the activation of the $70-\mathrm{kD}$ S6 kinase by insulin. Thus, investigation of the influence of insulin resistance on the ability of insulin to regulate kinases that in turn phosphorylate and activate the $70-\mathrm{kD}$ S6 kinase $(40,41)$ may lead to the primary defect in insulin signal transduction that results in insulin resistance in the Pima Indians.

Lavoinne et al. reported purification of an insulin-stimulated protein kinase that is similar to S6 kinase II (a $r s k$ kinase) both enzymatically and immunologically (42). Insulin-stimulated protein kinase appears to mediate phosphorylation of site 1 in the G-component of glycogen-bound type 1 phosphatase (PP1-G) that is associated with increased activity of PP1-G in response to insulin (43). Thus, the $r s k$ kinase(s) may have a broader role in insulin action than phosphorylation of S6 protein. Because ribosomal protein S6 is a poor substrate for $r s k$ kinase, our results do not resolve the question of whether insulin resistance affects the activation of $r s k$ kinase by insulin. Use of an alternative substrate, S6 peptide (RRLSSLRA), which is a better substrate for $r s k$ than for 70-kD S6 kinase, did not clarify this point, since we found evidence of at least four insulin-stimulated S6 peptide kinase activities in extracts of human skeletal muscle (data not shown). Attempts to specifically assay rsk by immunoprecipitation were unsuccessful. This question concerning $r s k$ activation in insulin resistance will be important to resolve, since abnormal activation of $r s k$ kinase may explain impaired insulin activation of type 1 phosphatase in insulin-resistant Pima Indians (9).

\section{Acknowledgments}

We thank the nursing staff for their care of the subjects and for assistance in performing clinical procedures, Dr. James Weiel (University of Seattle, Seattle, WA) for instructions on purification of 40 S ribosomes and assay of S6 kinase activity, Dr. Joseph Avruch (Massachusetts General Hospital) and Dr. Raymond Erikson (Harvard University) for providing antisera to S6 kinases, and Ethel Pfeilschifter for secretarial assistance.

This work was supported by the Intramural Program of the National Institute of Diabetes and Digestive and Kidney Diseases. 


\section{References}

1. Yamashita, T., W. Mackay, N. B. Rushforth, P. H. Bennett, and H. Houser. 1984. Pedigree analysis of noninsulin dependent diabetes mellitus in the Pima Indians suggests a dominant mode of inheritance. Am. J. Hum. Genet. 36(Suppl.):183s. (Abstr.)

2. Eriksson, J., A. Franssila-Kallunki, A. Ekstrand, C. Saloranta, E. Widen, C. Schalin, and L. Groop. 1989. Early metabolic defects in persons at increased risk for noninsulin-dependent diabetes mellitus. N. Engl. J. Med. 321:337-343.

3. Moller, D. E., A. Yokota, and J. S. Flier. 1989. Normal insulin-receptor cDNA sequence in Pima Indians with NIDDM. Diabetes. 38:1496-1500.

4. Cama, A., A. P. Patterson, T. Kadowaki, H. Kadowaki, G. Siegel, D. Dambrosio, S. Lillioja, J. Roth, and S. I. Taylor. 1990. The amino acid sequence of the insulin receptor is normal in an insulin-resistant Pima Indian. J. Clin. Endocrinol. \& Metab. 70:1155-1161.

5. Nyomba, B. L., V. M. Ossowski, C. Bogardus, and D. M. Mott. 1990. Insulin-sensitive tyrosine kinase-relationship with in vivo insulin action in humans. Am. J. Physiol. 258:E964-E974.

6. McGuire, M. C., R. M. Fields, B. L. Nyomba, I. Raz, C. Bogardus, N. K. Tonks, and J. Sommercorn. 1991. Abnormal regulation of protein tyrosine phosphatase activities in skeletal muscle of insulin-resistant humans. Diabetes 40:939-942.

7. Freymond, D., C. Bogardus, M. Okubo, K. Stone, and D. Mott. 1988 Impaired insulin-stimulated muscle glycogen synthase activation in vivo in man is related to low fasting glycogen synthase phosphatase activity. J. Clin. Invest. 82:1503-1509.

8. Kida, Y. A., A. Esposito-Del Puente, C. Bogardus, and D. M. Mott. 1990 Insulin resistance is associated with reduced fasting and insulin-stimulated glycogen synthase phosphatase activity in human skeletal muscle. J. Clin. Invest. 85:476-481.

9. Kida, Y., I. Raz, R. Maeda, B. L. Nyomba, K. Stone, C. Bogardus, J. Sommercorn, and D. M. Mott. 1992. Defective insulin response of phosphorylase phosphatase in insulin-resistant humans. J. Clin. Invest. 89:610-617.

10. Maeda, R., I. Raz, F. Zurlo and J. Sommercorn. 1991. Activation of skeletal muscle casein kinase II by insulin is not diminished in subjects with insulin resistance. J. Clin. Invest. 87:1017-1022.

11. Czech, M. P., J. K. Klarlund, K. A. Yagaloff, A. P. Bradford, and R. E. Lewis. 1988. Insulin receptor signaling: activation of multiple serine kinases. $J$. Biol. Chem. 263:11017-11020.

12. World Health Organization. 1985. Diabetes Mellitus: Report of WHO Study Group, Geneva. Technical Report Series, No. 727

13. Terao, K., and K. Ogata. 1970. Preparation and some properties of active subunits from rat liver ribosomes. Biochem. Biophys. Res. Commun. 38:80-85.

14. Laemmli, U. K. 1970. Cleavage of structural proteins during the assembly of the head of bacteriophage T4. Nature (Lond.). 227:680-685.

15. Bradford, M. M. 1976. A rapid and sensitive method for the quantitation of microgram quantities of protein utilizing the principle of protein-dye binding. Anal. Biochem. 72:248-254.

16. Sommercorn, J., and E. G. Krebs. 1987. Induction of casein kinase II during differentiation of 3T3-L1 cells. J. Biol. Chem. 262:3839-3843.

17. Erikson, E., and J. L. Maller. 1985. A protein kinase from Xenopus eggs specific for ribosomal protein S6. Proc. Natl. Acad. Sci. USA. 82:742-746.

18. Erikson, E., and J. L. Maller. 1986. Purification and characterization of a protein kinase from Xenopus eggs highly specific for ribosomal protein S6. $J$. Biol. Chem. 261:350-355.

19. Erikson, R. L. 1991. Structure, expression and regulation of protein kinases involved in the phosphorylation of ribosomal protein S6. J. Biol. Chem. 266:6007-6010.

20. Alcorta, D. A., C. M. Crews, L. J. Sweet, L. Bankston, S. W. Jones, and R. L. Erikson. 1989. Sequence and expression of chicken and mouse $r s k$ : homologs of Xenopus laevis ribosomal S6 kinase. Mol. Cell. Biol. 9:3850-3859.

21. Tabarini, D., A. Garcia de Herreros, J. Heinrich, and O. M. Rosen. 1987. Purification of a bovine liver S6 kinase. Biochem. Biophys. Res. Comm. 144:891899.

22. Blenis, J., C. J. Kuo, and R. L. Erikson. 1987. Identification of a ribosomal protein S6 kinase regulated by transformation and growth-promoting stimuli. $J$. Biol. Chem. 262:14373-14376.

23. Jeno, P., L. M. Ballou, I. Novak-Hofer, and G. Thomas. 1988. Identification and characterization of a mitogen-activated S6 kinase. Proc. Natl. Acad. Sci. USA. 85:406-410.

24. Gregory, J. S., T. G. Boulton, B.-C. Sang, and M. H. Cobb. 1989. An insulin-stimulated ribosomal protein S6 kinase from rabbit liver. J. Biol. Chem. 264:18397-18401.

25. Price, D. J., R. A. Nemenoff, and J. Avruch. 1989. Purification of a hepatic S6 kinase from cycloheximide-treated rats. J. Biol. Chem. 264:1382513833.

26. Bogardus, C. 1989. Perspective: does insulin resistance primarily affect skeletal muscle? Diabetes Metab. Rev. 5:567-568.

27. Lillioja, S., D. M. Mott, B. V. Howard, P. H. Bennett, H. Yki-Jarvinen, D. Freymond, B. L. Nyomba, F. Zurlo, B. Swinburn, and C. Bogardus. 1988. Impaired glucose tolerance as a disorder of insulin action. Longitudinal and crosssectional studies in Pima Indians. N. Engl. J. Med. 318:1217-1225.

28. Lopez-Alarcon, L., M. Mojena, L. Monge, and J. E. Feliu. 1986. Stimulation of pyruvate kinase phosphatase activity by insulin in isolated rat hepatocytes. Biochem. Biophys. Res. Comm. 134:292-298.

29. Chan, C. P., S. J. McNall, E. G. Krebs, and E. H. Fischer. 1988. Stimulation of protein phosphatase activity by insulin and growth factors in 3T3 cells. Proc. Natl. Acad. Sci. USA. 85:6257-6261.

30. Taylor, S. I., T. Kadowaki, H. Kadowaki, D. Accili, A. Cama, and C. McKeon. 1990. Mutations in insulin-receptor gene in insulin-resistant patients. Diabetes Care. 13:257-279.

31. Ponzio, G., J. O. Contreres, A. Debant, V. Baron, N. Gautier, J. D. Kitabgi, and B. Rossi. 1988. Use of an anti-insulin receptor antibody to discriminate between metabolic and mitogenic effects of insulin: correlation with receptor autophosphorylation. EMBO (Eur. Mol. Biol. Organ.) J. 7:4111-4117.

32. Debant, A., E. Clauser, G. Ponzio, C. Filloux, C. Auzan, J. O. Contreres, and B. Rossi. 1988. Replacement of insulin receptor tyrosine residues 1162 and 1163 does not alter the mitogenic effect of the hormone. Proc. Natl. Acad. Sci. USA. 85:8032-8036.

33. Thies, R. S., A. Ullrich, and D. A. McClain. 1989. Augmented mitogenesis and impaired metabolic signaling mediated by a truncated insulin receptor. $J$. Biol. Chem. 264:12820-12825.

34. Wilden, P. A., J. M. Backer, C. R. Kahn, D. A. Cahill, G. J. Schroeder, and M. F. White. 1990. The insulin receptor with phenylalanine replacing tyrosine1146 provides evidence for separate signals regulating cellular metabolism and growth. Proc. Natl. Acad. Sci. USA. 87:3358-3362.

35. Bogardus, C., S. Lillioja, D. Mott, G. R. Reaven, A. Kashiwagi, and J. E. Foley. 1984. Relationship between obesity and maximal insulin-stimulated glucose uptake in vivo and in vitro in Pima Indians. J. Clin. Invest. 73:800-805.

36. Bogardus, C., S. Lillioja, D. M. Mott, C. Hollenbeck, and G. Reaven. 1985. Relationship between degree of obesity and in vivo insulin action in man Am. J. Physiol 248(Endocrinol. Metab. 11):E286-E291.

37. Bogardus, C., S. Lillioja, and P. H. Bennett. 1991. Pathogenesis of NIDDM in Pima Indians. Diabetes Care. 14(Suppl. 3):685-690.

38. DeFronzo, R. A. 1979. Glucose intolerance and aging: evidence for tissue insensitivity to insulin. Diabetes. 28:1095-1101.

39. Fink, R. I., O. G. Kolterman, J. Griffin, and J. M. Olefsky. 1983. Mechanisms of insulin resistance in aging. J. Clin. Invest. 71:1523-1535.

40. Price, D. J., N. K. Mukhopadhyay, and J. Avruch. 1991. Insulin-activated protein kinases phosphorylate a pseudosubstrate synthetic peptide inhibitor of the p70 S6 kinase. J. Biol. Chem. 266:16281-16284.

41. Mukhopadhyay, N. K., D. J. Price, J. M. Kyriakis, S. Pelech, J. Sanghera, and J. Avruch. 1992. An array of insulin-activated, proline-directed serine/ threonine protein kinases phosphorylate the p70 S6 kinase. J. Biol. Chem. 267:3325-3335.

42. Lavoinne, A., E. Erikson, J. L. Maller, D. J. Price, J. Avruch, and P. Cohen. 1991. Purification and characterisation of the insulin-stimulated protein kinase from rabbit skeletal muscle; close similarity to S6 kinase II. Eur. J. Biochem. 199:723-728.

43. Dent, P., A. Lavoinne, S. Nakielny, F. B. Caudwell, P. Watt, and P. Cohen. 1990. The molecular mechanism by which insulin stimulates glycogen synthesis in mammalian skeletal muscle. Nature (Lond.). 348:302-308. 